\title{
Article
}

\section{End pharmacists' monopoly on selling certain drugs}

\author{
Rutter, Paul \\ Available at https://clok.uclan.ac.uk/14203/ \\ Rutter, Paul orcid iconORCID: 0000-0003-4106-1515 (2015) End pharmacists' \\ monopoly on selling certain drugs. thebmj . ISSN 0959-8138
}

It is advisable to refer to the publisher's version if you intend to cite from the work. http://dx.doi.org/10.1136/bmj.h3415

For more information about UCLan's research in this area go to http://www.uclan.ac.uk/researchgroups/ and search for < name of research Group>.

For information about Research generally at UCLan please go to http://www.uclan.ac.uk/research/

All outputs in CLoK are protected by Intellectual Property Rights law, including Copyright law. Copyright, IPR and Moral Rights for the works on this site are retained by the individual authors and/or other copyright owners. Terms and conditions for use of this material are defined in the policies page.

\section{CLoK}

Central Lancashire online Knowledge www.clok.uclan.ac.uk

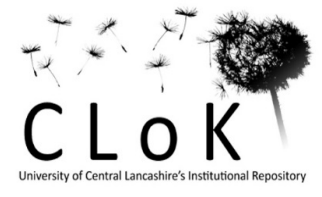


type=other in-section=views id=rutp025177 in-journal=bmj elocation-id=h3415 doi=10.1136/bmj.h3415

\section{Personal View}

\section{End pharmacists' monopoly on selling certain drugs}

\section{Paul Rutter}

professor of pharmacy practice, School of Pharmacy, University of Wolverhampton, Wolverhampton WV1 1SB

paul.rutter@wlv.ac.uk

Evidence is lacking that oversight by pharmacists has benefits, writes Paul Rutter, who thinks that the US dichotomy of prescription-only and non-prescription drugs is simpler 1778

In January 2015 the UK Medicines and Healthcare Products Regulatory Agency

announced that oral diclofenac would no longer be available as a non-prescription drug sold exclusively under the direction of a pharmacist (a “pharmacy medicine”). Instead, it would revert to prescription-only control because of a small but notably increased risk of cardiovascular side effects.[1]

Despite oral diclofenac having previously been restricted to sale through pharmacies the UK regulator decided that risks could not be ruled out-even in short term use and at lower doses than those prescribed. This implies that, even with this system of restricted availability, doubt exists that pharmacists (and their staff) can supervise sales to consumers appropriately.

Given this decision, should any drugs still be restricted to sale only with a pharmacist's supervision? Globally, many governments have healthcare policies that advocate for less prescription-only control of drugs. The mechanism for deregulation varies, but consumers worldwide can access drugs more easily than ever before.[2] Use of non-prescription drugs is the most prevalent form of medical care in the world, with a global market worth an estimated $€ 73 b n$ ( $£ 52 b n ; \$ 82 b n$ ), and their sales growth now exceeds that of prescriptiononly drugs.[3]

Many countries (including Australia, Canada, France, New Zealand, Sweden, and the United Kingdom) foster the declassification of drugs that are under prescription-only control by having a category of drugs that can be bought only at a pharmacy. These "pharmacy medicines" must be sold either by pharmacists or under their supervision. In the past 30 years this approach to reclassification has seen many therapeutic agents made available to consumers without a prescription, including proton pump inhibitors (in the United States and the European Union), orlistat (EU), triptans (UK and Germany), and $\beta_{2}$ agonists (Singapore and Australia). 


\section{Helping patients care for themselves}

Some may argue that the "pharmacy medicines" category helps pharmacists in the community to help patients care for themselves[4] and that the more drugs become available this way, the more opportunity this gives pharmacists to reduce people's need to access general medical services, thereby reducing doctors’ workloads.[5]

These arguments have been used by government and pharmacy organisations to champion a bigger role for community pharmacists. This may seem sensible and appropriate; pharmacies manage large numbers of consumers who seek advice and help for many minor illnesses.[2] [두] But does their 4-6 years of drug training mean that they should have a monopoly on selling some drugs? The evidence indicates not.

Firstly, community pharmacists may well act as a "screen,” effectively triaging people away from doctors' surgeries by supplying these drugs, but doctors still have a high caseload of minor illness. In part, this is because recent reclassifications from prescription-only control to pharmacy medicines have all come with extra conditions to their sale, compared with when they are dispensed under prescription. (For example, UK pharmacists cannot give 1\% hydrocortisone to children under 10, and "cautions in use" for triptans when prescribed by doctors became contraindications for retail sale.) This often results in consumers having to seek the drug through prescription from their doctor.

Pharmacists have also questioned the value and use of some drugs that have been recently deregulated to "pharmacy medicines,"[7] and consumer demand for some of these drugs has been low: in the UK, for example, poor sales led to the withdrawal of simvastatin.

Secondly, and more importantly, if pharmacy is to hold a monopoly on selling some medicines it needs to show value to consumers in terms of health outcomes, when compared with consumers purchasing these drugs without restriction. Evidence is lacking on this, but what is known is that community pharmacy practice has been criticised over its ability to sell pharmacy medicines appropriately all of the time.[8-10] More research is needed to establish whether and how pharmacists' intervention affects patient outcomes. Furthermore, questions have been raised about pharmacists' diagnostic ability, which tends to use rigid and established questioning strategies.[11][12]

\section{Time for a two tier system}

In the UK in the past four years just three drugs were switched from prescription-only control to pharmacy medicine status, but 12 pharmacy medicines were switched to general retail sale. The need for a "pharmacy medicines” category seems limited, especially as government policies seek to widen drugs' availability. The decision to switch diclofenac back 
to prescription-only control will surely make manufacturers more cautious in seeking pharmacy medicine status for their prescription-only drugs, especially as the deregulatory process is lengthy, complex, and costly.

In conclusion, without credible evidence to support the pharmacy medicines monopolynamely, that pharmacy intervention improves patient outcomes-it is only a matter of time before a two tier system of prescription or non-prescription drugs becomes the standard model, as in the US.

This system is easy to understand: access to medicines is obtained either with a prescription or from any retail outlet. This is less confusing for consumers and increases accessibility, but it still allows pharmacies to sell drugs and gives them a chance to demonstrate their worth.

Pull quote-Even with a system of restricted availability, doubt exists that pharmacists can supervise sales to consumers appropriately

Provenance and peer review: Not commissioned; externally peer reviewed.

Competing interests: I have read and understood the BMJ policy on declaration of interests and declare the following interests: I did paid consultancy work for Novartis Consumer Healthcare in September 2014 to give a community pharmacist's perspective on how the risk in diclofenac identified by the Medicines and Healthcare Products Regulatory Agency could be mitigated.

1 Medicines and Healthcare Products Regulatory Agency. Oral diclofenac presentations with legal status “P”-reclassified to POM. 14 Jan 2015. www.gov.uk/drug-devicealerts/drug-alert-oral-diclofenac-presentations-with-legal-status-p-reclassified-to-pom.

2 World Self Medication Industry. SWITCH: prescription to non-prescription medicines switch. 2009. www.wsmi.org/wp-content/data/pdf/wsmi_switchbrochure.pdf.

3 Tisman A. The rising tide of OTC in Europe. IMS Health 2010. www.imshealth.com/deployedfiles/imshealth/Global/Content/Healthcare/Healthcare\% 20Solutions/Consumers/The_Rising_Tide_Of_OTC_Europe.pdf.

4 Paudyal V, Hansford D, Cunningham S, Stewart D. Pharmacy assisted patient self care of minor ailments: a chronological review of UK health policy documents and key events 1997-2010. Health Policy 2011;101:253-9.

5 Pillay N, Tisman A, Kent T, Gregson J. The economic burden of minor ailments on the National Health Service (NHS) in the UK. SelfCare 2010;1:105-16.

6 World Self Medication Industry. Responsible self care and self medication-a worldwide review of consumer surveys. 2014. www.wsmi.org/wpcontent/data/pdf/wsmibro3.pdf. 
7 Paudyal V, Hansford D, Cunningham S, Stewart D. Pharmacists’ adoption into practice of newly reclassified medicines from diverse therapeutic areas in Scotland: a quantitative study of factors associated with decision making. Res Social Adm Pharm 2014;10:88-105.

8 Consumers' Association. Counter advice: which way to health? 1999;3:22-5.

9 Which? Pharmacies get test of own medicine. 25 Sept 2008. www.which.co.uk/news/2008/09/pharmacies-get-test-of-own-medicine-157330/.

10 Driesen A, Vandenplas Y. How do pharmacists manage acute diarrhoea in an 8 month old baby? A simulated client study. Int J Pharm Pract 2009;17:215-20.

11 Akhtar S, Rutter P. Pharmacists thought processes in making a differential diagnosis using a gastro-intestinal case vignette. Res Social Adm Pharm 2015;11:472-9.

12 Rutter P, Patel J. Decision making by community pharmacists when making an overthe-counter diagnosis in response to a dermatological presentation. SelfCare 2013;4:125-33.

Cite this as: $B M J$ 2015;350:h3415 